\title{
Colorectal Cancer in North-Eastern Iran: a retrospective, comparative study of early- onset and late-onset cases based on data from the Iranian hereditary colorectal cancer registry
}

Benyamin Hoseini ${ }^{1} \mathbb{0}$, Zahra Rahmatinejad ${ }^{2}$, Ladan Goshayeshi, ${ }^{3,4^{*}}$, Robert Bergquist ${ }^{5,6}{ }^{\mathbb{C}}$, Amin Golabpour $^{7}$, Kamran Ghaffarzadegan ${ }^{8}$, Fatemeh Rahmatinejad ${ }^{9}$, Reza Darrudi ${ }^{10}$ and Saeid Eslami ${ }^{1,2,11^{*}}$

\begin{abstract}
Background: The incidence rate of colorectal cancer (CRC) is increasing among patients below 50 years of age. The reason for this is unclear, but could have to do with the fact that indicative variables, such as tumour location, gender preference and genetic preponderance have not been followed up in a consistent mann er. The current study was primarily conducted to improve the hereditary CRC screening programme by assessing the demographic and clinicopathological characteristics of early-onset CRC compared to late-onset CRC in northeast Iran.
\end{abstract}

Methods: This retrospective study, carried out over a three-year follow-up period (2014-2017), included 562 consecutive CRCs diagnosed in three Mashhad city hospital laboratories in north-eastern Iran. We applied comparative analysis of pathological and hereditary features together with information on the presence of mismatch repair (MMR) gene deficiency with respect to recovery versus mortality. Patients with mutations resulting in absence of the MMR gene MLH1 protein product and normal BRAF status were considered to be at high risk of Lynch syndrome (LS). Analyses using R studio software were performed on early-onset CRC $(n=222)$ and late-onset CRC $(n=340)$, corresponding to patients $\leq 50$ years of age and patients $>50$ years.

Results: From an age-of-onset point of view, the distribution between the genders differed with females showing a higher proportion of early-onset CRC than men ( $56 \%$ vs. $44 \%$ ), while the late-onset CRC disparity was less pronounced (48\% vs. 52\%). The mean age of all participants was $55.6 \pm 14.8$ years, with $40.3 \pm 7.3$ years for early-onset CRC and $65.1 \pm 9.3$ years for late-onset CRC. With respect to anatomical tumour location (distal, rectal and proximal), the frequencies were 61,28 and 11\%, respectively, but the variation did not reach statistical significance. However, there was a dramatic difference with regard to the history of CRC in second-degree relatives between two age categories, with much higher numbers of family-related CRCs in the early-onset group. Expression of the MLH1 and PMS2

\footnotetext{
*Correspondence: GoshayeshiL@mums.ac.ir; EslamiS@mums.ac.ir

${ }^{4}$ Surgical Oncology Research Center, Mashhad University of Medical Sciences, Mashhad, Iran

${ }^{11}$ Department of Medical Informatics, Academic Medical Center, University of Amsterdam, Amsterdam, the Netherlands

Full list of author information is available at the end of the article
}

(C) The Author(s) 2022. Open Access This article is licensed under a Creative Commons Attribution 4.0 International License, which permits use, sharing, adaptation, distribution and reproduction in any medium or format, as long as you give appropriate credit to the original author(s) and the source, provide a link to the Creative Commons licence, and indicate if changes were made. The images or other third party material in this article are included in the article's Creative Commons licence, unless indicated otherwise in a credit line to the material. If material is not included in the article's Creative Commons licence and your intended use is not permitted by statutory regulation or exceeds the permitted use, you will need to obtain permission directly from the copyright holder. To view a copy of this licence, visit http://creativecommons.org/licenses/by/4.0/. The Creative Commons Public Domain Dedication waiver (http://creativeco mmons.org/publicdomain/zero/1.0/) applies to the data made available in this article, unless otherwise stated in a credit line to the data. 
genes were significantly different between recovered and deceased, while this finding was not observed with regard to the MSH6 and the MSH2 genes. Mortality was significantly higher in those at high risk of LS.

Conclusion: The variation of demographic, pathological and genetic characteristics between early-onset and lateonset CRC emphasizes the need for a well-defined algorithm to identify high-risk patients.

Keywords: Early-onset CRC, colon cancer, Colorectal cancer, Mismatch repair, cancer screening, cancer registry

\section{Introduction}

Approximately 1.2 million people suffer from colorectal cancer (CRC), the third most deadly cancer worldwide [1]. In spite of overall decreasing CRC rates, particularly in patients older than 50 years [2], the trend is the opposite in younger patients [3, 4]. Between 1975 and 2010, the annual incidence rate per 100,000 of 20-49 year olds increased by $1.5 \%$ among males and $1.6 \%$ per year among females [3, 5]. Thus, although recent screening programmes by colonoscopy for CRC and other lower-intestine disorders have contributed to an overall decrease of the CRC incidence through the detection and elimination of precancerous polyps, this is not evident in those younger than 50 years $[4,6]$.

According to several studies, the incidence early-onset CRC (affecting those $<50$ years of age) varies between different parts of the world with nearly $20 \%$ of the cases found in Asia including the Middle East (where the disease is not unusual in $<40$-year olds) as compared to $2-8 \%$ reported in the U.S. [7, 8]. The mean age of earlyonset CRC ranges between 37 and 47 years around the world [5, 7-18] and $41-69 \%$ of these cases are men. Compared to Western World (Europe and the U.S.), the incidence of CRC is currently very low in the older Iranian population, while young Iranians are showing a rising trend [19]. GLOBOCAN 2018 [20] tells us that the incidence of CRC could double in Iran before 2040.

The reason for the rising incidence and mortality of early-onset CRCs is unclear. Some authors suggest that the growing trend may be related to changing lifestyles, with an increasingly common type of patients characterized by overweight as evidenced by $>25$ body mass index (BMI) and low physical activity, often also being current smokers, non-aspirin users and (pre) diabetics [7, 21-25]. A meta-analysis indicates that a CRC history in a first-degree relative (FDR), hyperlipidaemia, obesity and alcohol consumption are significant risk factors for early-onset CRC, while smoking, hypertension, metabolic syndrome, ulcerative colitis, chronic kidney disease, certain dietary factors, sedentary behaviour and occupational exposure to organic dusts can also be potential risk factors [26]. Biologically, CRC in young patients may be different from that seen in patients above 50 years of age. Previous studies have shown that CRC is mainly left-sided in young patients [12,13] and particularly common in distal colon and rectum [12, 13, 27]. In addition, advanced-stage CRC with atypical histology has become more likely in younger patients, and they need more aggressive therapy compared to older individuals [28]. Current studies show that $94 \%$ of all early-onset CRCs are discovered and diagnosed after presenting with symptoms - the most predominant ones being abdomi$\mathrm{nal} /$ rectal pain and bleeding - something that indicates advanced stage with poor outcome [19,29].

Considering the growing trend of this disease in younger patients, we need to integrate knowledge of early-onset CRC characteristics and differences to develop more precise and individualized screening and treatment strategies. So far, differences between earlyonset and late-onset CRC have been investigated in various populations and ethnics to gain a better understanding of this upcoming world-wide health issue [30, 31]. While the pathogenesis of the former has been widely studied in the context of either hereditary syndromes or sporadic cases in the Western World [32-36], epidemiological data and pathogenesis of this type of cancer are generally lacking in countries in the Asia [22]. Moreover, there are considerable diversities regarding tumour location, gender preference and survival [31, 3740], which need to be specified by region. To our knowledge, no study in Iran has addressed the characteristics of early-onset CRC with regard to screening and treatment strategies.

Some types of CRC are caused by a genetically inherited, autosomal disorder called the Lynch syndrome (LS) that increases the risk of many types of cancer, particularly CRC $[18,41-43]$. The disorder is diagnosed by molecular or immunohistochemistry (IHC) testing in patients with mutations in one of four mismatch repair (MMR) genes designated MLH1, PMS2, MSH6 and $M S H 2$. Hereditary CRC is a priority of the Iranian Hereditary Colorectal Cancer Registry (IHCCR) that aims to detect, register and follow these patients. So far, identification of CRCs and colorectal adenomas at high risk of developing into hereditary CRC is recommended [18, 41, 42], but this may not be enough. The current study was conducted to assess the demographic, genetic and clinicopathological characteristics of early-onset CRC compared to late-onset CRC in Iran, specifically to improve screening for hereditary CRC. 


\section{Materials and methods}

\section{Setting and participants}

We approached the problem through the retrospective study of a cohort of consecutive CRCs between April 2014 and February 2017 in Mashhad City in northeastern Iran. All patient information was obtained from three referral centres that included Imam Reza Hospital Laboratory, Mashhad Pathology Laboratory and Moayed Pathology Laboratory. Data on individuals without firm age information were discarded from the study, unless we were able to contact them and confirm how old they were at the time of diagnosis. With respect to other missing data, we considered each available item for each category and included also some variables with missing data as shown in Fig. 1 that illustrates the whole inclusion/exclusion process. Because of the variable availability of variables we ended up with different numbers of patients in the different categories. CRC cases at high risk of LS were included in IHCCR for later follow-up and genetic evaluation.

\section{Eligibility criteria}

All CRCs consecutively registered in the databases of the three referral centres were eligible for inclusion. Cases with missing age data and/or clinically detected polyposis ( $>10$ polyps) were excluded. In case of unavailability of the surgical pathology slides used for IHC screening, the colonoscopy biopsy blocks were used instead. However, if both pathology slides and biopsy blocks were unavailable, the cases were excluded.

\section{MMR proteins immunohistochemistry}

The diagnosis of MMR deficiency relies on the demonstration of absence of one or more gene protein products. We performed IHC for the four most common MMR proteins using the standard procedure based on primary monoclonal antibodies from Vitro SA, Master Diagnostica, Spain (https://www.vitro.bio/inicio), i.e. clone BS29 for MLH1, clone FE11 for MSH2, clone EP49 for MSH6 and clone BS29 for PMS2. Deparaffinized, rehydrated and heat-induced 4-mm tissue sections were used for epitope retrieval with the reaction visualized with Novolink polymer (Leica Company, Wetzlar, Germany). The slides

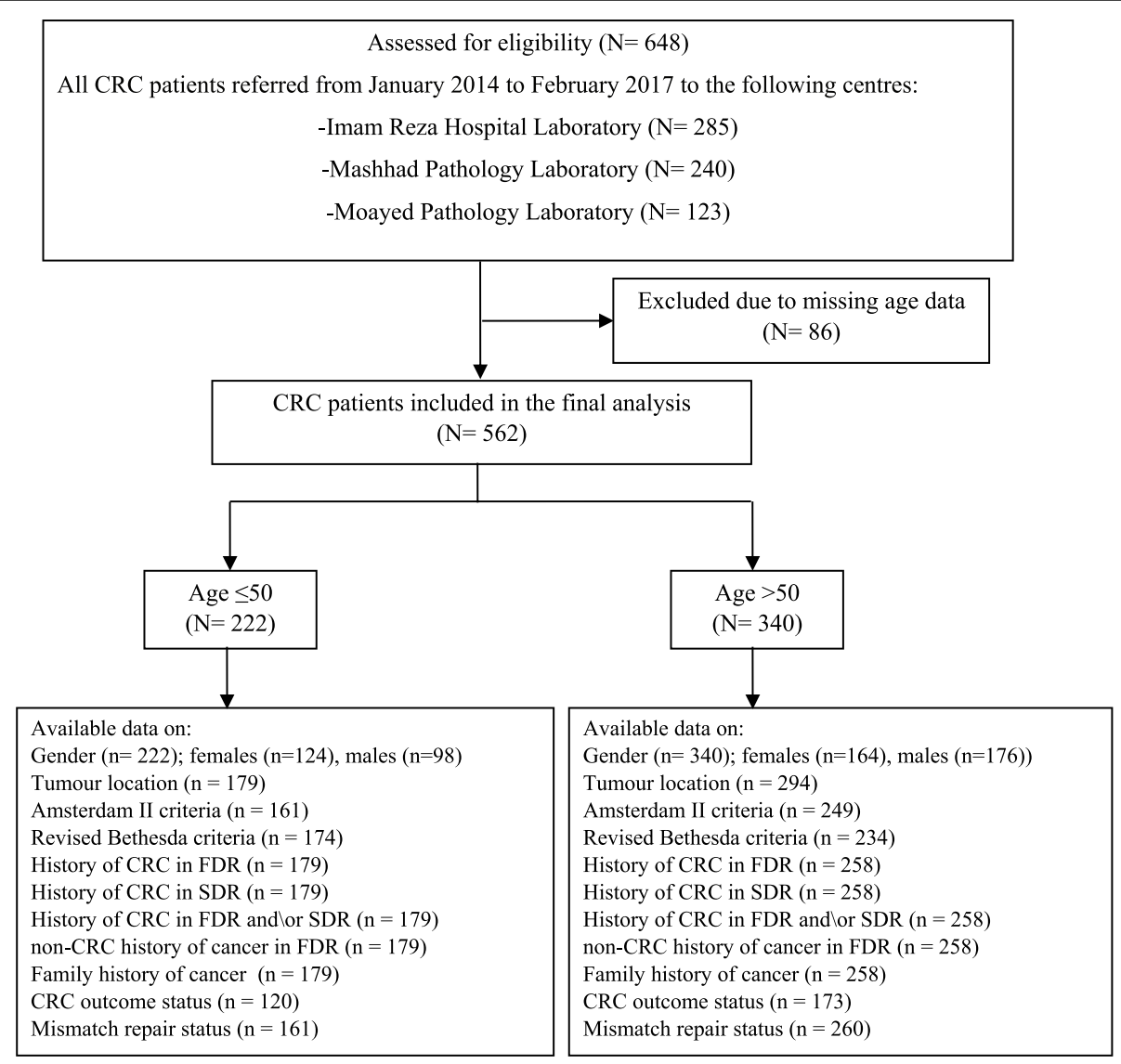

Fig. 1 Schematic diagram of the inclusion/exclusion process. $C R C=$ colorectal cancer; $F D R=$ first degree relative; $S D R=$ second degree relative 
were counterstained with haematoxylin and eosin. Two expert pathologists evaluated the results independently and blindly. All patients received therapy by surgery and chemotherapy according to CRC stage and oncologist opinion.

\section{Outcome measures and variables}

The Amsterdam II [44] and the revised Bethesda [45] guidelines were followed during the study to improve identification of individuals likely to have LS and therefore being at increased risk of developing CRC [18, 41, 42]. The screening for CRC in patients at high risk of LS focused on the protein products of the four MMR genes MLH1, MSH2, MSH6 and PMS2 as identified by absence of a specific IHC screening. To exclude sporadic CRCs with acquired promoter hypermethylation, tumours without IHC staining for $M L H 1$ were tested with reference to a mutation of the B-Raf proto-oncogene serine/ threonine kinase (BRAF) gene that could result in a valine-to-glutamate change at residue no. 600 (V600E) [16].

The secondary outcome measure was CRC outcome, which was based on the conclusion at the hospital (death or recovery and discharge). We compared available data between deceased and recovered patients with respect to gender, anatomical tumour location, status of the DNA MMR genes according to the Amsterdam II [44] and the revised Bethesda [45] criteria, CRC history in first and second degree relatives (FDR and SDR), as well as absence of CRC in the family history of cancer. Also, we compared these variables between early-onset and lateonset CRC.

\section{Statistical analyses}

The Chi-square test and the Fisher exact test were employed to identify any statistically significant differences in baseline characteristics in relation to age. The data were presented as percentage frequency of categorical variables and with the mean standard deviation (SD) for continuous variables. $P$-values $<0.05$ were considered statistically significant. All analyses were performed using R studio software (https://rstudio.com/).

\section{Results}

\section{Demographic characteristics}

As seen in Fig. 1, a total of 562 CRC cases were included in the study. The patients were divided into two categories depending on when the diagnosis was made: earlyonset CRC $(n=222)$ with patients $\leq 50$ years of age and late-onset CRC $(n=340)$ with those older than that. The participants' ages ranged from 20 to 90 years with a mean age of $55.63 \pm 14.8$ years. In the early-onset CRC group, the mean age was $40.34 \pm 7.3$ years, while it was
$65.11 \pm 9.3$ years in the late-onset group. The overall gender distribution was close to equal (51\% females vs. $49 \%$ males). The outcomes in relation to the different characteristics studied for the two age categories are shown in Table 1; however, because this was a retrospective study, we were unable to collect all data for all variables investigated, which is given for each entry in the Table.

\section{Clinicopathological characteristics}

With respect to the early-onset CRC and late-onset CRC categories, there was a statistically significant difference between the two age categories at the $p=0.03$ level. Interestingly, women made up the majority of early-onset CRCs compared to the late-onset ones. The anatomical tumour location varied considerably between the two types of CRC, but did not reach statistical significance, although it was evident that distal colorectal tumours were in majority (61\%), particularly in early-onset CRC (62\%). The Amsterdam II criteria were mostly present among the early-onset CRCs, and $42 \%$ of them had MMR-deficiencies as well. The Revised Bethesda criteria reinforced this impression and at a stronger level of statistical significance (Table 1). About $83 \%$ of patients had no history of CRC, neither in FDR nor in SDR, and around 14\% of 437 CRCs had non-CRC history of cancer in FDR, the most common being gastric cancer, breast cancer and lung cancer. Generally, there was no statistically significant difference between the early-onset $\mathrm{CRC}$ and late-onset CRC groups with respect to history of CRC in FDR; however there was a drastic difference with regard to history of CRC in SDR. Among 437 CRCs, about $33 \%$ had reported family history of cancer (Table 1).

\section{IHC screening}

With regard to IHC investigation, we had only access to 41 patients, several of whom had more than one kind of MMR-deficiency (dMMR). Although the percentage of MMR-deficiency in the early-onset CRC group was greater than that in the late-onset one, this difference was not significant. Twenty-eight cases with loss of $M L H 1$ underwent testing for the BRAF mutation, 5 of whom were recognized as positive for the BRAF mutation and excluded as sporadic CRC. Finally, 36 of 41 dMMR CRCs with mean age of $51.9 \pm 14.1$ years were detected as being at high risk of LS (Table 1).

\section{CRC outcome}

Of 293 CRCs with available outcome, 20\% passed away, a fact that was significantly more common among the late-onset CRCs than the early-onset CRC ones (Table 1). Several features between the deceased and the recovered groups, including deficient expression of 
Table 1 Baseline characteristics of the study participants

\begin{tabular}{|c|c|c|c|}
\hline Characteristic & Early-onset CRC (\%) & Late-onset CRC (\%) & $P$-value \\
\hline \multicolumn{4}{|l|}{ Gender $(n=562)$} \\
\hline Female $(n=288)$ & $124(55.9)$ & $164(48.2)$ & \multirow[t]{2}{*}{$0.046^{c}$} \\
\hline Male $(n=274)$ & $98(44.1)$ & $176(51.8)$ & \\
\hline \multicolumn{4}{|l|}{ Tumour location ( $n=473$ ) } \\
\hline Proximal $(n=53)$ & $16(8.9)$ & $37(12.6)$ & \multirow{3}{*}{$0.47^{c}$} \\
\hline Distal $(n=287)$ & $111(62.0)$ & $176(59.9)$ & \\
\hline Rectum $(n=133)$ & $52(29.1)$ & $81(27.6)$ & \\
\hline \multicolumn{4}{|l|}{ Amsterdam II $(n=410)$} \\
\hline Criteria absent $(n=395)$ & $151(93.8)$ & $244(98.0)$ & \multirow[t]{2}{*}{$0.03^{c}$} \\
\hline Criteria present $(n=15)$ & $10(6.2)$ & $5(2.0)$ & \\
\hline \multicolumn{4}{|l|}{ Revised Bethesda $(n=408)$} \\
\hline Criteria absent $(n=212)$ & $14(8.0)$ & $198(84.6)$ & \multirow[t]{2}{*}{$0.001^{c}$} \\
\hline Criteria present $(n=196)$ & $160(92.0)$ & $36(15.4)$ & \\
\hline \multicolumn{4}{|l|}{ History of CRC in FDR $(n=437)$} \\
\hline No $(n=395)$ & $162(90.5)$ & $235(90.3)$ & \multirow[t]{2}{*}{$0.9^{c}$} \\
\hline Yes $(n=42)$ & $17(9.5)$ & $25(9.7)$ & \\
\hline \multicolumn{4}{|l|}{ History of CRC in SDR $(n=437)$} \\
\hline No $(n=399)$ & $154(86.0)$ & $245(95.0)$ & \multirow[t]{2}{*}{$0.001^{c}$} \\
\hline Yes $(n=38)$ & $25(14.0)$ & $13(5.0)$ & \\
\hline \multicolumn{4}{|l|}{ History of CRC in FDR or SDR $(n=437)$} \\
\hline No $(n=362)$ & $141(78.8)$ & $221(85.7)$ & \multirow[t]{2}{*}{$0.06^{c}$} \\
\hline Yes $(n=75)$ & $38(21.2)$ & $37(14.3)$ & \\
\hline \multicolumn{4}{|l|}{ History of CRC in FDR and SDR $(n=437)$} \\
\hline No $(n=432)$ & $175(97.8)$ & $257(99.6)$ & \multirow[t]{2}{*}{$0.16^{d}$} \\
\hline Yes $(n=5)$ & $4(2.2)$ & $1(0.4)$ & \\
\hline \multicolumn{4}{|l|}{ non-CRC history of cancer in FDR ( $n=437)$} \\
\hline No $(n=374)$ & $155(86.6)$ & $219(84.9)$ & \multirow[t]{2}{*}{$0.6^{c}$} \\
\hline Yes $(n=63)$ & $24(13.4)$ & $39(15.1)$ & \\
\hline \multicolumn{4}{|l|}{ Family history of cancer $(n=437)$} \\
\hline Absent $(n=291)$ & $114(63.7)$ & $177(68.6)$ & \multirow[t]{2}{*}{$0.3^{c}$} \\
\hline Present $(n=146)$ & $65(36.3)$ & $81(31.4)$ & \\
\hline \multicolumn{4}{|l|}{ CRC outcome group ( $n=293)$} \\
\hline Recovered and discharged $(n=234)$ & $103(85.8)$ & $131(75.7)$ & \multirow[t]{2}{*}{$0.03^{c}$} \\
\hline Deceased at the hospital $(n=59)$ & $17(14.2)$ & $42(24.3)$ & \\
\hline \multicolumn{4}{|l|}{ Mismatch repair status $(n=421)$} \\
\hline Proficient $(n=380)$ & $143(88.8)$ & $237(91.1)$ & \multirow[t]{2}{*}{$0.39^{d}$} \\
\hline Deficient $(n=41)$ & $18(11.2)$ & $23(8.9)$ & \\
\hline At high risk for $L S^{\mathrm{a}}(n=421)$ & & & \\
\hline No $(n=385)$ & $143(88.8)$ & $242(93.1)$ & \\
\hline Yes $(n=36)$ & $18(11.2)$ & $18(6.9)$ & $0.14^{\mathrm{d}}$ \\
\hline MMR-deficiency ${ }^{\mathrm{b}}(n=41$ ( & $18(43.9)$ & $23(56.1)$ & \\
\hline$M L H 1(n=27)$ & $13(48.1)$ & $14(51.9)$ & \\
\hline PMS2 $(n=30)$ & $13(43.3)$ & $17(56.7)$ & $0.3^{d}$ \\
\hline MSH2 $(n=9)$ & $4(44.4)$ & $5(55.6)$ & \\
\hline MSH6 $(n=10)$ & $5(50.0)$ & $5(50.0)$ & \\
\hline
\end{tabular}

$C R C$ colorectal cancer, FDR first degree relative, SDR second degree relative, $L S$ Lynch syndrome, MMR mismatch repair

a $\mathrm{CRC}$ s with absent MMR proteins, and normal BRAF status (if $M L H 1$ was absent)

b Some MMR gene deficiencies included more than one protein, which explains why the sum exceeds 41

c Analysis by Chi-square test

d Analysis by Fisher's exact test 
the MSH6 and MSH2 genes; the Amsterdam- II/revised Bethesda criteria, as well as the tumour location, did not reach statistical significance. However, age, presence of deficient $M L H 1$ and PMS2 genes as well as risk for LS stood out as high-impact variables (Table 2).

\section{Discussion}

Multiple studies have focused on clarifying the characterization of CRC based on the age of onset [5, 46]. However, to our knowledge, this is the first study in Iran to assess the demographic, clinicopathological and hereditary features in cases diagnosed before 50 years,

Table 2 Various features in the group of patients studied with respect to CRC outcome

\begin{tabular}{|c|c|c|c|c|}
\hline $\begin{array}{l}\text { CRC outcome } \\
\text { Variable }\end{array}$ & $\begin{array}{l}\text { Recovered }=234 \\
\text { Number }(\%)\end{array}$ & $\begin{array}{l}\text { Deceased = } 59 \\
\text { Number (\%) }\end{array}$ & $\begin{array}{l}\text { Total }=293 \\
\text { Number (\%) }\end{array}$ & $P$-value \\
\hline Continuous age - mean (SD) & $53.58(14.11)$ & $59.25(16.88)$ & $54.72(14.86)$ & 0.009 \\
\hline \multicolumn{5}{|l|}{ Age range (years) } \\
\hline $20-29$ & $8(3.4)$ & $3(5.1)$ & $11(3.8)$ & \\
\hline $30-39$ & $31(13.2)$ & $6(10.2)$ & $37(12.6)$ & \\
\hline $40-49$ & $55(23.5)$ & $8(13.6)$ & $63(21.5)$ & $0.03^{d}$ \\
\hline $50-59$ & $57(24.4)$ & $11(18.6)$ & $68(23.2)$ & \\
\hline $60-69$ & $40(17.1)$ & $10(16.9)$ & $50(17.1)$ & \\
\hline $70-79$ & $35(15.0)$ & $13(22.0)$ & $48(16.4)$ & \\
\hline$\geq 80$ & $8(3.4)$ & $8(13.6)$ & $16(5.5)$ & \\
\hline \multicolumn{5}{|l|}{ Gender } \\
\hline Female & $156(49.0)$ & $29(49.0)$ & $185(49.0)$ & $0.9^{c}$ \\
\hline Male & $159(51.0)$ & $30(51.0)$ & $189(51.0)$ & \\
\hline \multicolumn{5}{|l|}{ Amsterdam II } \\
\hline Criteria absent & $196(95.1)$ & $53(96.3)$ & $249(95.0)$ & $0.7^{c}$ \\
\hline Criteria present & $10(4.9)$ & $2(3.7)$ & $12(5.0)$ & \\
\hline \multicolumn{5}{|l|}{ Tumour location } \\
\hline Proximal & $30(14.2)$ & $6(10.9)$ & $36(13.5)$ & $0.2^{c}$ \\
\hline Distal & $126(59.4)$ & $28(50.9)$ & $154(57.7)$ & \\
\hline Rectum & $56(26.4)$ & $21(38.2)$ & $77(28.8)$ & \\
\hline \multicolumn{5}{|l|}{ Mismatch repair status } \\
\hline Proficient & $143(92.0)$ & $31(77.5)$ & $174(89.0)$ & $0.02^{C}$ \\
\hline Deficient & $13(8.0)$ & $9(22.5)$ & $22(11.0)$ & \\
\hline \multicolumn{5}{|l|}{ At high risk for $L^{a}$} \\
\hline No & 145 (93.0) & $32(80.0)$ & $177(90.0)$ & $0.03^{c}$ \\
\hline Yes & $11(7.0)$ & $8(20.0)$ & $19(10.0)$ & \\
\hline \multicolumn{5}{|l|}{ MLHI } \\
\hline pMMR & $147(94.0)$ & $34(85.0)$ & $181(92.0)$ & $0.05^{\complement}$ \\
\hline $\mathrm{dMMR}$ & $9(6.0)$ & $6(15.0)$ & $15(8.0)$ & \\
\hline \multicolumn{5}{|l|}{ PMS2 } \\
\hline pMMR & $145(94.0)$ & $33(82.0)$ & $178(91.0)$ & $0.02^{c}$ \\
\hline $\mathrm{dMMR}$ & $10(6.0)$ & $7(18.0)$ & $17(9.0)$ & \\
\hline \multicolumn{5}{|l|}{ MSH2 } \\
\hline pMMR & 152 (98.0) & 38 (95.0) & $190(97.0)$ & $0.27^{c}$ \\
\hline $\mathrm{dMMR}$ & $3(2.0)$ & $2(5.0)$ & $5(3.0)$ & \\
\hline \multicolumn{5}{|l|}{ MSH6 } \\
\hline pMMR & $153(98.0)$ & $38(95.0)$ & $191(97.0)$ & $0.27^{c}$ \\
\hline $\mathrm{dMMR}$ & $3(2.0)$ & $2(5.0)$ & $5(3.0)$ & \\
\hline
\end{tabular}

$C R C$ colorectal cancer, MMR mismatch repair, $P M M R$ mismatch repair proficiency, dMMR mismatch repair-deficiency, LS Lynch syndrome

a Defined as the CRC cases with absent MMR proteins and normal BRAF status (if MLH1 was absent)

c Analysis by Fisher's exact test

${ }^{d}$ Analysis by Chi-square test 
the age generally used to separate early-onset from lateonset CRC. Although several features (Amsterdam-II, Revised Bethesda, tumour location, deficient expression of the MSH6 and MSH2 genes) did not reach statistical significance, others (LS risk and deficient expression of the MLH1 and PMS2 genes) differed dramatically with respect to CRC outcome. Most CRC cases in the late-onset CRC group and those diagnosed as being at high risk of LS died prematurely because of the cancer. In spite of this fact, our results support the understanding that early-onset CRC is in a long-term, rising trend, while the opposite is true for late-onset CRC. These trends are evident at regional as well as country levels, e.g., an Italian study has shown that the incidence rate of CRC in patients aged 20-49years increased from 9.3 in 1957 to 13.7 in 2015, whereas the incidence rate of CRC in older patients has steadily declined [2]. Recent studies report incidence rates in CRC patients $\leq 50$ years in India [47] and in the central region of Iran [22] at 39 and $25 \%$, respectively. Furthermore, we found that more than $39 \%$ of our cases were first diagnosed with CRC when still under 50 years. We also found that the mean age for early-onset CRCs was 40 years and that the highest number of cases were in the final decade of the age range investigated (40-50years of age), which is in accordance with other studies $[9,11,16,48]$. However, this pattern is more pronounced in Asia than in the Western countries $[38,49-55]$.

In the last 10 years, a large number of research projects around the world have focused on early-onset CRC. The sample size of these studies ranged between 49 and 64,068 cases [5, 7-18, 48, 56-58] and the mean age of study subjects ranged between 37 and 47 years $[5,7-12$, 14-18]. In contrast to our study, the frequency of earlyonset CRC is generally reported to be higher in men than in women $[5,7,10,11,13-17,48]$, but various studies have yielded conflicting results [10, 28, 47,59]. Without finding any reason for the gender difference, we noted that early-onset CRC predominantly affected women, whereas late-onset CRC mainly involved men, which was statistically significant.

With regard to localization, our analysis revealed that $\mathrm{CRC}$ was less frequent in the proximal colon, which is consistent with results by some authors in the MiddleEast $[15,22,57,58]$. However, the results of other studies performed in the Western World diverge [31, 60], which suggests that there may be differences with regard to the pathogenesis and aetiology of this kind of tumour between the Middle-East and the West. In accordance with our results, which showed an identical distribution of distal tumours in both CRC groups, there seems to be no significant difference with respect to age and tumour location in different age groups $[28,37,61,62]$, On the other hand, the results of multiple other studies are not in line with these findings [10,47,63,64], so tumour localization remains a contended issue.

Although family history of cancer overall did not align with any of the two age categories studied at a statistical significant level, the presence of a positive history of CRC in SDR together with early-onset CRC was highly significant and the combination with either FDR or SDR did not reach significance. These observations confirm previous research results on this subject $[10,65]$.

It has been observed that tumour histology in younger patients often show poor differentiation with more aggressive growth compared to that seen in older patients $[66,67]$. Although this is generally negative for recovery, the overall 5-year relative survival rate for patients under 50 years is on the whole not shorter than for patients above this age [37, 40, 68, 69]. Indeed, despite young patients often present with more advanced disease, it is not unusual for them to survive longer, a counterintuitive fact that is supported by the significantly higher mortality for late-onset CRCs in our study. On the other hand, this must be seen in connection with the concomitant life expectancy.

Multiple risk factors contribute to CRC development. This has been assessed in Iran previously [70-72] and among the various factors affecting CRC incidence, the main reason for early-onset CRC development might be the various germline mutations that have come to light in the last two decades [18, 73]. Our study, in addition to demographic and pathological characteristics, addressed the MMR status of early-onset CRCs. Although this study could not confirm germline MMR mutations in other ways than by IHC, the assessment of CRC cases at high risk of LS with respect to age and outcome illuminated the background to how genetic aspects may play a role in CRC development by finding that CRC in those at high risk of LS was more prevalent in the deceased group. With $83 \%$ sensitivity and $89 \%$ specificity of IHC testing for absence of expression of MMR proteins in this group, we are confident that there is a connection. Tumours in LS cases also demonstrate microsatellite instability (MSI) owing to loss of DNA MMR, and testing for this by the polymerase chain reaction (PCR), which amplifies a standard panel of DNA sequences containing nucleotide repeats, has a sensitivity and specificity of about 85 and $90 \%$, respectively [43, 74]. Loss of the $M L H 1$ expression owing to hypermethylation of this protein is seen in about $15 \%$ of sporadic CRCs based on IHC screening [75]. On the other hand, cancers associated with the MSH6 protein may be missed during MSI testing because this gene is preferentially involved in repair of mononucleotide repeats and mononucleotide markers are not included in all MSI panels [43, 76]. In spite of the better 
sensitivity and specificity of MSI testing, IHC is cheap and easily available, can be conducted using small biopsies and has the added value of assisting identification of the MMR protein(s) that may have caused the dMMRrelated tumour.

\section{Strengths and limitations}

The multicentre design with a relatively large number of patients followed over a period of 3 years is the main strength of the present study. In addition, the study examines thoroughly the various features in terms of age group and CRC outcome. Since we were not able to contact all CRC cases, the number of patients to deal with changed between the variables as can be seen in Table 1 . This was the most challenging limitation, but what was available still allowed us to achieve acceptable power of the statistics used. We compared the characteristics of deceased and recovered CRC cases based on hospital mortality only for 293 consecutive CRCs. Thus, we could not perform survival analyses. However, this was not the aim of the study and will be addressed in future studies. Data, such as symptoms, socioeconomic status, BMI, past medical history, ethnicity, geographic and colonoscopy findings were not available for all cases and must be counted as another limitation as a complete dataset would have made a more detailed interpretation possible. Owing to lack of genetic testing in our setting, the study applied a strategy to identify CRC cases at high risk for LS under the circumstances and resources available. This made differentiation between true Lynch and Lynch-like cases difficult, but this limitation can be avoided in the future as genetic diagnosis is becoming available locally. Furthermore, due to lack of genetic evaluation, we aimed to detect polyposis clinically but no familial adenomatous (FAP) cases were found. The limitations mentioned impose a lack of generalizability of the findings and methods used to characterize early-onset CRCs, but we still think that the results will be useful for low- and middle-income countries especially in Middle East where their resources are as limited as in Iran.

\section{Conclusion}

With up to $57 \%$ of the early-onset CRC cases at ages of 40 and 49 , the mortality rate in this group was considerable. Furthermore, MMR deficiency and risk of LS in CRC patients was more common in the deceased group than among those who survived, but this difference was only significant with respect to the $M L H 1$ and PMS2 genes. In our study, women were in majority for early-onset CRC, while the opposite was the case for late-onset CRC. The incidence of CRC with distal tumours was frequently higher than for other sites, but there was no difference between the early-onset and late-onset CRC cases. Taken together, these findings highlight the need for a welldefined algorithm assisting the identification of patients at risk for early-onset CRC.

\section{Supplementary Information}

The online version contains supplementary material available at https://doi. org/10.1186/s12885-021-09132-5.

\section{Additional file 1.}

\section{Acknowledgments \\ We would like to thank Mashhad University of Medical Sciences for its supports.}

\section{Authors' contributions}

$B H, L G$, and SE contributed to the study design. All authors $(B H, Z R, L G, R B$, $F R, A G, K G, R D$, and $S E$ ) contributed to data gathering and interpretation of the results. $\mathrm{ZR}, \mathrm{BH}$, and $\mathrm{FR}$ performed analyses and wrote the first draft of the manuscript. RB edited the final version of the manuscript. All authors $(\mathrm{BH}$, $Z R$, LG, RB, FR, AG, KG, RD, and SE) read, commented, and approved the final manuscript.

\section{Funding}

This study was supported by National Institute for Medical Research Development (NIMAD) (grant number of 978991) and Mashhad University of Medical Sciences (grant number of 978991).

\section{Availability of data and materials}

The demographic and clinical datasets generated and/or analysed during the current study are available in the Harvard Dataverse repository, [https://doi. org/10.7910/DVN/HHLMA1]. The molecular genetic dataset used and/or analysed during the current study are available from the corresponding author (Dr. Ladan Goshayeshi) on reasonable request.

\section{Declarations}

Ethics approval and consent to participate

The study was approved by Ethics committee of Mashhad University of Medical Sciences (ethics code: IR.MUMS.REC.1396.164) and conformed to the ethical principles contained in Declaration of Helsinki. For experiments involving human participants (including the use of tissue samples), the participants signed an informed consent before the study.

\section{Consent for publication}

Not applicable.

\section{Competing interests}

The authors declare that they have no competing interests.

\section{Author details}

${ }^{1}$ Pharmaceutical Research Center, Mashhad University of Medical Sciences, Mashhad, Iran. ${ }^{2}$ Department of Medical Informatics, Faculty of Medicine, Mashhad University of Medical Sciences, Mashhad, Iran. ${ }^{3}$ Department of Gastroenterology and Hepatology, Faculty of Medicine, Mashhad University of Medical Sciences, Mashhad, Iran. ${ }^{4}$ Surgical Oncology Research Center, Mashhad University of Medical Sciences, Mashhad, Iran. ${ }^{5}$ Formerly UNICEF/ UNDP/World Bank/WHO Special Programme for Research and Training in Tropical Diseases (TDR), World Health Organization, Geneva, Switzerland ${ }^{6}$ Ingerod, SE-454 94 Brastad, Sweden. ${ }^{7}$ School of Paramedical, Shahroud University of Medical Sciences, Shahroud, Iran. ${ }^{8}$ Pathology Department, Education and Research Department, Razavi Hospital, Mashhad, Iran. ${ }^{9}$ Department of Health Information Technology, Faculty of Paramedical Sciences, Mashhad University of Medical Sciences, Mashhad, Iran. ${ }^{10}$ Department of Health Information Technology, Neyshabur University of Medical Sciences, Neyshabur, Iran. ${ }^{11}$ Department of Medical Informatics, Academic Medical Center, University of Amsterdam, Amsterdam, the Netherlands. 
Received: 28 December 2020 Accepted: 21 December 2021 Published online: 08 January 2022

\section{References}

1. Rawla P, Sunkara T, Barsouk A. Epidemiology of colorectal cancer: incidence, mortality, survival, and risk factors. Przegl Gastroenterol. 2019;14(2):89.

2. Russo A, Andreano A, Sartore-Bianchi A, Mauri G, Decarli A, Siena S. Increased incidence of colon cancer among individuals younger than 50 years: a 17 years analysis from the cancer registry of the municipality of Milan. Italy Cancer Epidemiol. 2019;60:134-40.

3. Bailey CE, Hu CY, You YN, Bednarski BK, Rodriguez-Bigas MA, Skibber JM, et al. Increasing disparities in the age-related incidences of colon and rectal cancers in the United States, 1975-2010. JAMA Surg. 2015;150(1):17-22. https://doi.org/10.1001/jamasurg.2014.1756 PubMed PMID: 25372703; PubMed Central PMCID: PMCPMC4666003.

4. Siegel RL, Jemal A, Ward EM. Increase in incidence of colorectal cancer among young men and women in the United States. Cancer Epidemiol Prev Biomark. 2009;18(6):1695-8.

5. Arriba M, Sánchez C, Vivas A, Nutu O, Rueda D, Tapial S, et al. Intermediate-onset colorectal cancer: a clinical and familial boundary between both early and late-onset colorectal cancer. PLoS One. 2019;14(5):e0216472.

6. Jalili-Nik M, Soltani A, Moussavi S, Ghayour-Mobarhan M, Ferns GA, Hassanian SM, et al. Current status and future prospective of Curcumin as a potential therapeutic agent in the treatment of colorectal cancer. J Cell Physiol. 2018;233(9):6337-45. https://doi.org/10.1002/jcp.26368.

7. Montazeri M, Hoseini B, Firouraghi N, Kiani F, Raouf-Mobini H, Biabangard $A$, et al. Spatio-temporal mapping of breast and prostate cancers in South Iran from 2014 to 2017. BMC cancer. 2020;20(1):1170. Epub 2020/12/02. https://doi.org/10.1186/s12885-020-07674-8. PubMed PMID: 33256668; PubMed Central PMCID: PMCPMC7708260.

8. Glover M, Mansoor E, Panhwar M, Parasa S, Cooper GS. Epidemiology of colorectal Cancer in average risk adults 20-39 years of age: a populationbased National Study. Dig Dis Sci. 2019;64(12):3602-9.

9. You YN, Xing Y, Feig BW, Chang GJ, Cormier JN. Young-onset colorectal cancer: is it time to pay attention? Arch Intern Med. 2012;172(3):287-9.

10. Myers EA, Feingold DL, Forde KA, Arnell T, Jang JH, Whelan RL. Colorectal cancer in patients under 50 years of age: a retrospective analysis of two institutions' experience. World J Gastroenterol. 2013;19(34):5651-7. https://doi.org/10.3748/wjg.v19.i34.5651 Epub 2013/09/17. PubMed PMID: 24039357; PubMed Central PMCID: PMCPMC3769901.

11. Perrott S, Laurie K, Laws K, Johnes A, Miedzybrodzka Z, Samuel L. Youngonset colorectal cancer in the north east of Scotland: survival, clinicopathological features and genetics. BMC Cancer. 2020;20(1):108.

12. Zhunussova G, Afonin G, Abdikerim S, Jumanov A, Perfilyeva A, Kaidarova $D$, et al. Mutation spectrum of cancer-associated genes in patients with early onset of colorectal cancer. Front Oncol. 2019:9:673.

13. Ferlay J, Soerjomataram I, Dikshit R, Eser S, Mathers C, Rebelo M, et al. Cancer incidence and mortality worldwide: sources, methods and major patterns in GLOBOCAN 2012. Int J Cancer. 2015;136(5):E359-E86.

14. Rashid MU, Naeemi H, Muhammad N, Loya A, Lubiński J, Jakubowska A, et al. Prevalence and spectrum of MLH1, MSH2, and MSH6 pathogenic germline variants in Pakistani colorectal cancer patients. Hereditary Cancer Clin Pract. 2019;17(1):29.

15. Maraqa B, Al-Shbool G, Abu-Shawer O, Souleiman M, Alshakhatreh O, AlOmari $A$, et al. Frequency of mismatch repair protein (MMRP) deficiency among young jordanians diagnosed with Colorectal Carcinoma (CRC). Gastroenterol Res Pract. 2020;2020:5632984. https://doi.org/10.1155/ 2020/5632984 Epub 2020/05/10. PubMed PMID: 32382267; PubMed Central PMCID: PMCPMC7195647.

16. Ashktorab H, Brim H, Al-Riyami M, Date A, Al-Mawaly K, Kashoub M, et al. Sporadic colon cancer: mismatch repair immunohistochemistry and microsatellite instability in Omani subjects. Dig Dis Sci. 2008;53(10):272331. https://doi.org/10.1007/s10620-007-0189-3 Epub 2008/02/27. PubMed PMID: 18299982

17. Gausman V, Dornblaser D, Anand S, Hayes RB, O'Connell K, Du M, et al. Risk Factors Associated With Early-Onset Colorectal Cancer. Clin Gastroenterol Hepatol. 2020;18(12):2752-9.e2. https://doi.org/10.1016/j.cgh.
2019.10.009 Epub 2019/10/18. PubMed PMID: 31622737; PubMed Central PMCID: PMCPMC7153971.

18. Goshayeshi L, Ghaffarzadegan K, Khooei A, Esmaeilzadeh A, Rahmani Khorram M, Mosannen Mozaffari H, et al. Prevalence and clinicopathological characteristics of mismatch repair-deficient colorectal carcinoma in early onset cases as compared with late-onset cases: a retrospective cross-sectional study in Northeastern Iran. BMJ Open. 2018;8(8):e023102. https://doi.org/10.1136/bmjopen-2018-023102 Epub 2018/09/01. PubMed PMID: 30166308; PubMed Central PMCID: PMCPMC6119423.

19. Malekzadeh R, Bishehsari F, Mahdavinia M, Ansari R. Epidemiology and molecular genetics of colorectal cancer in iran: a review. Archives of Iranian medicine. 2009;12(2):161-9. Epub 2009/03/03. PubMed PMID: 19249887.

20. Bray F, Ferlay J, Soerjomataram I, Siegel RL, Torre LA, Jemal A. Global cancer statistics 2018: GLOBOCAN estimates of incidence and mortality worldwide for 36 cancers in 185 countries. CA Cancer J Clin. 2018;68(6):394-424. https://doi.org/10.3322/caac.21492 Epub 2018/09/13. PubMed PMID: 30207593.

21. Sudarshan V, Hussain N, Gahine R, Mourya J. Colorectal cancer in young adults in a tertiary care hospital in Chhattisgarh, Raipur. Indian J Cancer. 2013;50(4):337.

22. Zeinalian M, Hashemzadeh-Chaleshtori M, Akbarpour MJ, Emami $\mathrm{MH}$. Epidemioclinical feature of early-onset colorectal Cancer at-risk for Lynch syndrome in Central Iran. Asian Pac J Cancer Prev: APJCP. 2015;16(11):4647-52.

23. Esmaeilzadeh A, Goshayeshi L, Bergquist R, Jarahi L, Khooei A, Fazeli A, et al. Characteristics of gastric precancerous conditions and Helicobacter pylori infection among dyspeptic patients in north-eastern Iran: is endoscopic biopsy and histopathological assessment necessary? BMC Cancer. 2021;21(1):1143. https://doi.org/10.1186/s12885-021-08626-6 Epub 2021/10/28. PubMed PMID: 34702194; PubMed Central PMCID: PMCPMC8546943.

24. Goshayeshi L, Hoseini B, Yousefli Z, Khooie A, Etminani K, Esmaeilzadeh A, et al. Predictive model for survival in patients with gastric cancer. Electron Physician. 2017;9(12):6035-42. https://doi.org/10.19082/6035 Epub 2018/03/22. PubMed PMID: 29560157; PubMed Central PMCID: PMCPMC5843431.

25. Azizi A, Aboutorabi R, Mazloum-Khorasani Z, Hoseini B, Tara M. Diabetic personal health record: a Ssystematic review article. Iran J Public Health 2016;45(11):1388-98 Epub 2016/12/30. PubMed PMID: 28032056; PubMed Central PMCID: PMCPMC5182247.

26. O'Sullivan DE, Sutherland RL, Town S, Chow K, Fan J, Forbes N, et al. Risk factors for early-onset colorectal Cancer: a systematic review and Metaanalysis. Clin Gastroenterol Hepatol. 2021. https://doi.org/10.1016/j.cgh 2021.01.037 Epub 2021/02/02. PubMed PMID: 33524598.

27. Ladan Goshayeshi, Mina Akbari Rad, Robert Bergquist, Abolghasem Allahyari, members of the MUMS Covid-19 Research Team, Benyamin Hoseini. Demographic and Clinical Characteristics of the Severe Covid-19 Infections: First Report from Mashhad University of Medical Sciences, Iran. medRxiv. 2020:2020.05.20.20108068. https://doi.org/10.1101/2020.05.20. 20108068.

28. De Silva M, Fernando M, Fernando D. Comparison of some clinical and histological features of colorectal carcinoma occurring in patients below and above 40 years. Ceylon Med J. 2000;45(4):166-7.

29. Siegel $R L$, Sahar $L$, Robbins A, Jemal A. Where can colorectal cancer screening interventions have the most impact? Cancer Epidemiol Prev Biomark. 2015;24(8):1151-6.

30. Schellerer V, Croner R, Langheinrich M, Hohenberger W, Merkel S. Colorectal carcinoma in young patients-is age a prognostic factor? Zentralbl Chir. 2015;140(6):600-6.

31. Perea J, Rueda D, Canal A, Rodríguez Y, Álvaro E, Osorio I, et al. Age at onset should be a major criterion for subclassification of colorectal cancer. J Mol Diagn. 2014;16(1):116-26.

32. Popat $\mathrm{S}$, Hubner R, Houlston RS. Systematic review of microsatellite instability and colorectal cancer prognosis. J Clin Oncol. 2005;23(3):609-18. https://doi.org/10.1200/jco.2005.01.086 Epub 2005/01/22. PubMed PMID: 15659508.

33. Chang DT, Pai RK, Rybicki LA, Dimaio MA, Limaye M, Jayachandran P, et al. Clinicopathologic and molecular features of sporadic early-onset colorectal adenocarcinoma: an adenocarcinoma with frequent signet ring cell differentiation, rectal and sigmoid involvement, and adverse 
morphologic features. Mod Pathol. 2012;25(8):1128-39. https://doi.org/ 10.1038/modpathol.2012.61 PubMed PMID: 22481281.

34. Jandova J, Xu W, Nfonsam V. Sporadic early-onset colon cancer expresses unique molecular features. J Surg Res. 2016;204(1):251-60. https://doi. org/10.1016/j.jss.2016.04.068 PubMed PMID: 27451894

35. Pilozzi E, Lorenzon L, Lo Baido S, Ferri M, Duranti E, Fochetti F, et al. Left-sided early onset colorectal carcinomas: a sporadic neoplasm with aggressive behavior. Am J Surg. 2017;214(3):421-7. https://doi.org/10. 1016/j.amjsurg.2017.01.035 PubMed PMID: 28173936.

36. Stigliano V, Sanchez-Mete L, Martayan A, Anti M. Early-onset colorectal cancer: a sporadic or inherited disease? World I Gastroenterol. 2014;20(35):12420-30. https://doi.org/10.3748/wjg.v20.i35.12420 PubMed PMID: 25253942; PubMed Central PMCID: PMCPMC4168075.

37. Schellerer V, Croner R, Langheinrich M, Hohenberger W, Merkel S. Colorectal carcinoma in young patients - is age a prognostic factor? Zentralbl Chir. 2015;140(6):600-6. https://doi.org/10.1055/s-0032-1328570 Epub 2013/07/13. PubMed PMID: 23846539

38. Mahdavinia M, Bishehsari F, Ansari R, Norouzbeigi N, Khaleghinejad A, Hormazdi M, et al. Family history of colorectal cancer in Iran. BMC Cancer. 2005:5:112. https://doi.org/10.1186/1471-2407-5-112 PubMed PMID: 16143045; PubMed Central PMCID: PMCPMC1208868.

39. Kurzawski G, Suchy J, Debniak T, Kladny J, Lubinski J. Importance of microsatellite instability (MSI) in colorectal cancer: MSI as a diagnostic tool. Ann Oncol. 2004;15(Suppl 4):iv283-4. https://doi.org/10.1093/annonc/ mdh940 PubMed PMID: 15477322.

40. Lee PY, Fletcher WS, Sullivan ES, Vetto JT. Colorectal cancer in young patients: characteristics and outcome. Am Surg. 1994;60(8):607-12 Epub 1994/08/01. PubMed PMID: 8030817.

41. Goshayeshi L, Khooiee A, Ghaffarzadegan K, Rahmani Khorram M, Bishehsari F, Hoseini B, et al. Screening for Lynch syndrome in cases with colorectal carcinoma from Mashhad. Arch Iran Med. 2017:20(6):332-7 Epub 2017/06/26. PubMed PMID: 28646840.

42. Khorram MR, Goshayeshi L, Maghool F, Bergquist R, Ghaffarzadegan $\mathrm{K}$, Eslami S, et al. Prevalence of mismatch repair-deficient colorectal adenoma/polyp in early-onset, advanced cases: a cross-sectional study based on Iranian hereditary colorectal Cancer registry. J Gastrointest Cancer. 2020. https://doi.org/10.1007/s12029-020-00395-y Epub 2020/03/21. PubMed PMID: 32193764.

43. Lagerstedt Robinson K, Liu T, Vandrovcova J, Halvarsson B, Clendenning $\mathrm{M}$, Frebourg T, et al. Lynch syndrome (hereditary nonpolyposis colorectal cancer) diagnostics. J Natl Cancer Inst. 2007;99(4):291-9. Epub 2007/02/22. https://doi.org/10.1093/jnci/djk051. PubMed PMID: 17312306.

44. Vasen HF, Watson P, Mecklin JP, Lynch HT. New clinical criteria for hereditary nonpolyposis colorectal cancer (HNPCC, Lynch syndrome) proposed by the international collaborative group on HNPCC. Gastroenterology. 1999;1 16(6):1453-6. https://doi.org/10.1016/s0016-5085(99)70510-x Epub 1999/05/29. PubMed PMID: 10348829.

45. Umar A, Boland CR, Terdiman JP, Syngal S, de la Chapelle A, Rüschoff J, et al. Revised Bethesda Guidelines for hereditary nonpolyposis colorectal cancer (Lynch syndrome) and microsatellite instability. J Natl Cancer Inst. 2004;96(4):261-8. https://doi.org/10.1093/jnci/djh034 Epub 2004/02/19. PubMed PMID: 14970275: PubMed Central PMCID: PMCPMC2933058.

46. Jacobs D, Zhu R, Luo J, Grisotti G, Heller DR, Kurbatov V, et al. Defining early-onset colon and rectal cancers. Front Oncol. 2018:8:504. https:// doi.org/10.3389/fonc.2018.00504 Epub 2018/11/22. PubMed PMID: 30460196: PubMed Central PMCID: PMCPMC6232522.

47. Sudarshan V, Hussain N, Gahine R, Mourya J. Colorectal cancer in young adults in a tertiary care hospital in Chhattisgarh. Raipur Indian J Cancer. 2013;50(4):337-40. https://doi.org/10.4103/0019-509X.123621 PubMed PMID: 24369213.

48. Aykan NF, Yalçın S, Turhal NS, Özdoğan M, Demir G, Özkan M, et al. Epidemiology of colorectal cancer in Turkey: a cross-sectional disease registry study (a Turkish oncology group trial). Turk J Gastroenterol. 2015;26(2):145-53. https://doi.org/10.5152/tjg.2015.5685 Epub 2015/04/04. PubMed PMID: 25835113

49. Ansari R, Mahdavinia M, Sadjadi A, Nouraie M, Kamangar F, Bishehsari F, et al. Incidence and age distribution of colorectal cancer in Iran: results of a population-based cancer registry. Cancer Lett. 2006;240(1):143-7. https://doi.org/10.1016/j.canlet.2005.09.004 Epub 2005/11/18. PubMed PMID: 16288832.
50. Malekzadeh R, Bishehsari F, Mahdavinia M, Ansari R. Epidemiology and molecular genetics of colorectal cancer in Iran: a review. Arch Iran Med. 2009;12(2):161-9 Epub 2009/03/03. PubMed PMID: 19249887.

51. Mousavi SM, Gouya MM, Ramazani R, Davanlou M, Hajsadeghi N, Seddighi Z. Cancer incidence and mortality in Iran. Ann Oncol. 2009;20(3):556-63. https://doi.org/10.1093/annonc/mdn642 Epub 2008/12/17. PubMed PMID: 19073863.

52. Fazeli MS, Adel MG, Lebaschi AH. Colorectal carcinoma: a retrospective, descriptive study of age, gender, subsite, stage, and differentiation in Iran from 1995 to 2001 as observed in Tehran University. Dis Colon Rectum. 2007;50(7):990-5. https://doi.org/10.1007/s10350-007-0248-z Epub 2007/05/26. PubMed PMID: 17525859.

53. Azadeh S, Moghimi-Dehkordi B, Fatem SR, Pourhoseingholi MA, Ghiasi S, Zali MR. Colorectal cancer in Iran: an epidemiological study. Asian Pac J Cancer Prev. 2008;9(1):123-6 Epub 2008/04/29. PubMed PMID: 18439090.

54. Siegel R, Desantis C, Jemal A. Colorectal cancer statistics, 2014. CA Cancer J Clin. 2014;64(2):104-17. https://doi.org/10.3322/caac.21220 Epub 2014/03/19. PubMed PMID: 24639052.

55. Sung JJ, Lau JY, Goh KL, Leung WK. Increasing incidence of colorectal cancer in Asia: implications for screening. Lancet Oncol. 2005;6(11):871-6. https://doi.org/10.1016/s1470-2045(05)70422-8 Epub 2005/11/01. PubMed PMID: 16257795

56. Ashktorab H, Vilmenay K, Brim H, Laiyemo AO, Kibreab A, Nouraie M. Colorectal cancer in young african americans: is it time to revisit guidelines and prevention? Dig Dis Sci. 2016;61 (10):3026-30. https://doi.org/ 10.1007/s10620-016-4207-1 Epub 2016/06/10. PubMed PMID: 27278956; PubMed Central PMCID: PMCPMC5021553.

57. Siraj AK, Prabhakaran S, Bavi P, Bu R, Beg S, Hazmi MA, et al. Prevalence of Lynch syndrome in a middle eastern population with colorectal cancer. Cancer. 2015;121(11):1762-71. https://doi.org/10.1002/cncr.29288 Epub 2015/02/26. PubMed PMID: 25712738.

58. Alqahtani M, Grieu F, Carrello A, Amanuel B, Mashour M, Alattas R, et al. Screening for Lynch syndrome in young colorectal Cancer patients from Saudi Arabia using microsatellite instability as the initial test. Asian Pac J Cancer Prev. 2016;17(4):1917-23. https://doi.org/10.7314/apjcp.2016.17.4. 1917 Epub 2016/05/26. PubMed PMID: 27221876.

59. Parramore JB, Wei JP, Yeh KA. Colorectal cancer in patients under forty: presentation and outcome. Am Surg. 1998;64(6):563-7 discussion 7-8. Epub 1998/06/10. PubMed PMID: 9619179.

60. Schofield L, Watson N, Grieu F, Li WQ, Zeps N, Harvey J, et al. Population-based detection of Lynch syndrome in young colorectal cancer patients using microsatellite instability as the initial test. Int J Cancer. 2009;124(5):1097-102. https://doi.org/10.1002/ijc.23863 Epub 2008/12/17. PubMed PMID: 19072991

61. Minardi AJ Jr, Sittig KM, Zibari GB, McDonald JC. Colorectal cancer in the young patient. Am Surg. 1998;64(9):849-53 Epub 1998/09/10. PubMed PMID: 9731812

62. Chiang JM, Chen MC, Changchien $C R$, Chen JS, Tang R, Wang JY, et al. Favorable influence of age on tumor characteristics of sporadic colorectal adenocarcinoma: patients 30 years of age or younger may be a distinct patient group. Dis Colon Rectum. 2003;46(7):904-10. https://doi.org/ 10.1097/01.dcr.0000075210.01797.11 Epub 2003/07/09. PubMed PMID: 12847364.

63. Palmer ML, Herrera L, Petrelli NJ. Colorectal adenocarcinoma in patients less than 40 years of age. Dis Colon Rectum. 1991;34(4):343-6 Epub 1991/04/01. PubMed PMID: 1706654.

64. Fante R, Benatti P, di Gregorio C, De Pietri S, Pedroni M, Tamassia MG, et al. Colorectal carcinoma in different age groups: a population-based investigation. Am J Gastroenterol. 1997;92(9):1505-9 Epub 1997/10/08. PubMed PMID: 9317073

65. Makela JT, Kiviniemi H. Clinicopathological features of colorectal cancer in patients under 40 years of age. Int J Color Dis. 2010;25(7):823-8. https:// doi.org/10.1007/s00384-010-0914-9 Epub 2010/03/11. PubMed PMID: 20217423.

66. Endreseth BH, Romundstad P, Myrvold HE, Hestvik UE, Bjerkeset T, Wibe A. Rectal cancer in the young patient. Dis Colon Rectum. 2006;49(7):9931001. https://doi.org/10.1007/s10350-006-0558-6 Epub 2006/06/03. PubMed PMID: 16741599

67. Moore PA, Dilawari RA, Fidler WJ. Adenocarcinoma of the colon and rectum in patients less than 40 years of age. Am Surg. 1984;50(1):10-4 Epub 1984/01/01. PubMed PMID: 6691626. 
68. Leff DR, Chen A, Roberts D, Grant K, Western C, Windsor AC, et al. Colorectal cancer in the young patient. Am Surg. 2007;73(1):42-7 Epub 2007/01/26. PubMed PMID: 17249455.

69. Eker B, Ozaslan E, Karaca H, Berk V, Bozkurt O, Inanc M, et al. Factors affecting prognosis in metastatic colorectal cancer patients. Asian Pac J Cancer Prev. 2015;16(7):3015-21 Epub 2015/04/10. PubMed PMID: 25854399.

70. Firouraghi N, Bagheri N, Kiani F, Goshayeshi L, Ghayour-Mobarhan M, Kimiafar K, et al. A spatial database of colorectal cancer patients and potential nutritional risk factors in an urban area in the Middle East. BMC Res Notes. 2020;13(1):466. https://doi.org/10.1186/s13104-020-05310-z Epub 2020/10/04. PubMed PMID: 33008452; PubMed Central PMCID: PMCPMC7532552.

71. Ali Dadashi, Alireza Mohammadi, Shahab MohammadEbrahimi, Robert Bergquist, Ali Shamsoddini, Azam Hesami, Elahe Pishgar, Khalil Kimiafar, Masoumeh Sarbaz \& Behzad Kiani (2021) |Spatial analysis of the 10 most prevalent cancers in north-eastern Iran, 2017-2018» Journal of Spatial Science. https://doi.org/10.1080/14498596.2021.1975583.

72. Kiani B, Amin FH, Bagheri N, Bergquist R, Mohammadi AA, Yousefi M, et al. Association between heavy metals and colon cancer: an ecological study based on geographical information systems in north-eastern Iran. BMC Cancer. 2021;21(1):1-12.

73. Chen J, Etzel CJ, Amos Cl, Zhang Q, Viscofsky N, Lindor NM, et al. Genetic variants in the cell cycle control pathways contribute to early onset colorectal cancer in Lynch syndrome. Cancer Causes Control. 2009;20(9):1769-77. https://doi.org/10.1007/s10552-009-9416-x Epub 2009/08/20. PubMed PMID: 19690970; PubMed Central PMCID: PMCPMC3917505.

74. Yaghoubi N, Soltani A, Ghazvini K, Hassanian SM, Hashemy SI. PD-1/ PD-L1 blockade as a novel treatment for colorectal cancer. Biomed Pharmacother. 2019;1 10:312-8. https://doi.org/10.1016/j.biopha.2018.11.105.

75. Parry S, Win AK, Parry B, Macrae FA, Gurrin LC, Church JM, et al. Metachronous colorectal cancer risk for mismatch repair gene mutation carriers: the advantage of more extensive colon surgery. Gut. 2011;60(7):950-7. https://doi.org/10.1136/gut.2010.228056 Epub 2011/01/05. PubMed PMID: 21193451; PubMed Central PMCID: PMCPMC3848416.

76. South CD, Hampel H, Comeras I, Westman JA, Frankel WL, de la Chapelle A. The frequency of Muir-Torre syndrome among Lynch syndrome families. J Natl Cancer Inst. 2008;100(4):277-81. https://doi.org/10.1093/jnci/ djm291 Epub 2008/02/14. PubMed PMID: 18270343.

\section{Publisher's Note}

Springer Nature remains neutral with regard to jurisdictional claims in published maps and institutional affiliations.

Ready to submit your research? Choose BMC and benefit from:

- fast, convenient online submission

- thorough peer review by experienced researchers in your field

- rapid publication on acceptance

- support for research data, including large and complex data types

- gold Open Access which fosters wider collaboration and increased citations

- maximum visibility for your research: over $100 \mathrm{M}$ website views per year

At BMC, research is always in progress.

Learn more biomedcentral.com/submissions 